\title{
PENINGKATAN KEMAMAMPAUN BERPIKIR DAN MENGANALISA MASALAH PADA PEMBELAJARAN IPS SISWA KELAS V SDN KASEPUHAN SEWON BANTUL DENGAN METODE PROBLEM SOLVING
}

\author{
Maya Kartika Sari *
}

\begin{abstract}
This research is served to describe: (1) the students' learning activitiesin problem solving techique; (2) students' courage to pose ideas; (3) students' ability to share ideas in problem solving technique; (4) students' ability in having the critical thinking in solving the learning problems. This research covers two cycles, each of which includes planning, implementing, controling, and reflecting. The subject of the research are 32 fifth graders of SD Negeri Kasepuhan Sewon Bantul being taught by problem solving technique to develop their critical thinking and problem solving skill of the Social Science subject. The results show that: (1) the students' activity develops from 5 active students in pre research stage to 10 in the first cycle; and it becomes 28 in the second cycle; (2) students' courage to pose ideas develops from 4 courageous students in pre research stage to 15 in the first cycle; and 25 in the second cycle; (3) the ability to share ideas develops from 7 capable students in pre research to 12 in the first cycle, and 26 in the second cycle; (4) the thinking skill develops from 2 skilled students in problem solving in pre research stage to 17 in the first cycle, and 24 in the second cycle. The results of the research recommends that poblem solving technique is efficient in developing students' activities, critical thinking skill and problem solving skill in the Social Science subject for the fifth graders of SD Negeri Kasepuhan Sewon Bantul.
\end{abstract}

Key words: Students' Learning Activities, Critical Thinking Skill, Problem Solving

\begin{abstract}
Abstrak
Penelitian ini bertujuan untuk mengetahui: (1) keaktifan siswa dalam pembelajaran melalui metode problem solving; (2) kemampuan siswa berpendapat; (3) kemampuan siswa dalam mengeluarkan pendapat dalam pembelajaran problem solving; dan (4) kemampuan siswa dalam berpikir kritis dalam memecahkan masalah pada pembelajaran problem solving. Penelitian ini terdiri dari 2 siklus, tiap siklus terdiri dari perencanaan, pelaksanaan, pengamatan, dan refleksi. Subjek penelitian adalah siswa kelas V SD Negeri Kasepuhan Sewon Bantul sejumlah 32 siswa dengan menerapkan metode problem solving untuk meningkatkan kemampuan berpikir dan menganalisa masalah siswa
\end{abstract}

\footnotetext{
* Maya Kartika Sari adalah Dosen Prodi PGSD FIP IKIP PGRI MADIUN
} 
matapelajaran IPS. Hasil penelitian yakni: (1) adanya peningkatan keaktifan siswa dari pra penelitian 5 siswa; kemudian pada siklus 1 sebanyak 10 siswa dan siklus 2 sebanyak 28 siswa; (2) adanya peningkatan kemampuan siswa dalam berpendapat dari prapenelitian 4 siswa menjadi 15 siswa (siklus 1) dan 25 siswa (siklus 2); (3) adanya peningkatan kemampuan berpendapat dari 7 siswa (pra) menjadi 12 siswa (siklus 1) dan 26 siswa (siklus 2); dan (4) adanya peningkatan kemampuan siswa berpikir kritis dalam memecahkan masalah dari pra 2 siswa meningkat menjadi 17 siswa (siklus 1) dan 24 siswa (siklus 2). Berdasarkan hasil penelitian diatas dapat disimpulkan bahwa terdapat peningkatan kemampuan berpikir dan menganalisa masalah pada matapelajaran IPS melalui metode pembelajaran problem solving di kelas V SD Negeri Kasepuhan Sewon Bantul.

\section{Kata kunci: Kemamampaun Berpikir, Menganalisa Masalah, Problem solving}

\section{A. PENDAHULUAN}

Pembelajaran Ilmu Pengetahuan Sosial (IPS) di sekolah dasar sangat penting dalam rangka memersiapkan kualitas sumber daya manusia (SDM) di era globalisasi saat ini. Melalui pembelajaran IPS diharapkan siswa mampu memiliki minat dan bakat dalam memahami, menghayati bahkan memecahkan masalah-masalah yang terjadi di lingkungan masyarakat. Harapannya dengan mempelajari IPS sejak dini kelak siswa akan menjadi pakar-pakar sosial yang mampu memberikan konstribusi terhadap pembangunan kehidupan berbangsa dan bernegara. Pembelajaran IPS di sekolah dasar jika dipantau dan dianalisa terdapat beberapa kendala yang muncul, hal ini dikarenakan pembelajaran IPS yang kurang inovatif, kreatif dan komunikatif, sehingga lebih terkesan kurang menarik dan monoton. Hal ini dikarenakan guru sebagai subjek dari pembelajaran kurang menerapkan metode belajar yang tepat ditambah dengan minimnya penggunaan media pembelajaran yang menarik dalam proses belajar mengajar di kelas.

Pembelajaran merupakan proses interaksi siswa dengan pengajar dan sumber belajar pada lingkungan belajar. Menurut Hamalik pembelajaran merupakan suatu sistem yang tersusun dari unsur-unsur manusiawi, material, fasilitas, perlengkapan dan prosedur yang saling mempengaruhi pencapaian tujuan pembelajaran. Seorang guru harus mampu berkomunikasi secara efektif dengan siswa-siswanya yang mempertanyakan alasan, arti, relevansi dari apa yang siswa pelajari. Dalam setiap pembelajaran terutama pembelajaran IPS harus memenuhi empat pilar pendidikan yang dikemukakan Unesco, yakni: (1) learning to know (belajar untuk memahami dan menghayati); (2) learning to be (belajar untuk membangun dan menenmukan jati diri); (3) learning to live together (belajar untuk hidup bersama dan berguna); dan (4) learning to do (belajar melaksanakan dan berbuat secara efektif).

Faktor penentu keberhasilan pembelajaran IPS dipengaruhi oleh beberapa faktor yakni penguasaan guru terhadap materi yang diajarkan, kemampuan guru dalam menyampaikan materi pelajaran dengan berbagai gaya mengajar dan variasi matode pembelajaran yang tepat, ketersediaan sarana dan prasarana pendukung pembelajaran, penguasaan dalam penggunaan media dan alat peraga pembelajaran, 
serta lingkungan beajar yang mendukung proses pembelajaran. Guru sebagai faktor penentu keberhasilan belajar perlu memperhatikan karakteristik siswa, interaksi guru dan siswa agar materi yang diajarkan dapat melekat di dalam pikiran siswa. Seorang guru perlu mengaplikasikan materi IPS dalam kehidupan sosial di masyarakat. Oleh karena itulah guru perlu mengembangkan daya pikir siswa dalam mengetahui, memahami dan menghayati permasalahan yang muncul di masyarakat, sehingga siswa mampu secara kritis menganalisa dan memecahkan permasalahan yang terdapat di lingkungan sekitar. Guru perlu menerapkan metode pembelajaran yang tepat dalam rangka pengembangan daya daya pikir dan analisa siswa, yakni dengan metode pembelajaran problem solving.

Problem solving merupakan suatu model pembelajaran yang memusatkan pada pengajaran dan ketrampilan memecahkan masalah yang dikaitkan dengan masalah-masalah sosial yang terjadi di masyarakat. Problem solving dalam pembelajaran IPS ini melibatkan siswa untuk berperan aktif dalam pembelajaran dengan bimbingan guru sehingga terjadi komunikasi dan berinteraksi aktif dalam pembelajaran, agar siswa dalam memahami konsep terarah lebih baik. Pembelajaran IPS di SD Negeri Kasepuhan Sewon Bantul terutama kelas V pada kenyataannya siswa merasa kurang bersemangat dalam pembelajaran, siswa merasa kurang terasah kemampuan berpikirnya dalam memecahkan masalah-masalah sosial di masyarakat, guru hanya menggunakan metode pembelajaran yang monoton, siswa kurang kritis dalam menjawab dan bertanya dalam pembelajaran, dan guru tidak mengkaitkan pelajaran dengan isu sosial di masyarakat. Berdasarkan analisa permasalahan diatas, peneliti berkolaborasi dengan guru menerapkan metode problem solving pada pembelajaran kelas V Negeri Kasepuhan Sewon Bantul pada materi Kegiatan ekonomi di Indonesia. Harapannya dengan pembelajaran problem solving mampu meningkatkan pembelajaran mata pelajaran IPS.

\section{B. KAJIAN PUSTAKA}

\section{Deskripsi Ilmu Pengetahuan Sosial}

Ilmu Pengetahuan Sosial menurut Cokrodikardjo (2012: 2) didefinisikan sebagai perwujudan suatu pendekatan interdisipliner dari ilmu sosial yang merupakan integritas dari berbagai ilmu sosial yakni sosiologi, antropologi budaya, psikologi, sejarah, geografi, ekonomi, ilmu politik dan ekologi manusia yang diformulasikan untuk tujuan instruksional dengan materi dan tujuan yang disederhanakan agar mudah dipahami. Menurut Winata (2007: 9) IPS adalah salah satu bidang studi yang mempunyai tujuan untuk mengembangkan penalarannya disamping aspek nilai dan moral, banyak memuat materi sosial dan bersifat hafalan sehingga pengetahuan dan informasi yang diterima siswa sebatas produk hafalan. Hal ini menunjukkan bahwa pembelajaran IPS tersebut kurang mampu mengembangkan daya pikir siswa.

Tujuan pembelajaran IPS menurut Harm (Winata, 2007: 8) adalah: (1) IPS untuk memenuhi kebutuhan individu. Hendaknya mempersiapkan persiapkan individu-individu menggunakan ilmu pengetahuannya untuk meningkatkan kehidupan mereka dan menjawab dunia teknologi yang semakin maju; (2) IPS untuk memecahkan berbagai persoalan-persoalan kemasyarakatan masa kini; dan (3) pendidikan IPS hendaknya membuka kesempatan kepada siswa yang ingin 
memperdalam ilmu pengetahuan yang secara akademik maupun profesional akan mendapatkan pengetahuan akademik yang tepat untuk memenuhi kebutuhannya.

Tujuan pembelajaran IPS menurut Jackson (2004): the purpose of sosial studies is to prepare youth for citizenship, there's also general agreement that the elements of a sound citizenship education are knowledge, skills, values, and participation. Sejalan dengan pendapat tersebut Cheft (1991) mengemukakan bahwa pembelajaran IPS berusaha membantu siswa dalam memecahkan permasalahan-permasalahan yang dihadapi, sehingga akan menjadikan semakin mengerti dan memahami lingkungan sosial masyarakatnya.

\section{Deskripsi Metode Pembelajaran Problem solving}

Pembelajaran problem solving adalah suatu kegiatan yang didesain oleh guru dalam rangka memberi tantangan kepada siswa melalui penugasan atau pertanyaan IPS (Tim PPPG IPS, 2005: 93). Dalam kegiatan pembelajaran guru memotivasi siswa agar menerima dan membimbing siswa dalam pemecahannya. Masalah yang diberikan harus masalah yang pemecahannya terjangkau oleh kemampuan siswa. Tujuan pembelajaran problem solving yang dikemukakan oleh Hudojo (2003:155) yakni: (1) siswa menjadi terampil menyeleksi informasi yang relevan kemudian menganalisinya dan akhirnya meneliti kembali hasilnya; (2) kepuasan intelektual timbul dari dalam sebagai hadiah instrinsik bagi siswa; (3) potensi intelektual meningkat; (4) siswa belajar bagaimana melakukan peneuan dengan melalui proses melakukan penemuan.

Berdasarkan tujuan pembelajaran tersebut, maka penerapan pembelajaran problem solving mengikuti langkah-langkah, yakni: (1) guru menyajikan masalah; (2) siswa memahami terlebih dahulu masalah yang disajikan; (3) siswa merencanakan tahap-tahap penyelesaian masalah; (4) siswa menentukan strategi-strategi pemecahan masalah; (5) siswa berupaya melaksanakan rencana dan strategi yang telah disusun sebelumnya untuk menyelesaikan masalah; dan (6) siswa melihat kembali penyelesaian masalah yang telah diambil kemudian dievaluasi dan direfleksi agar penyelesaian masalah berkualitas.

Dalam penerapan metode pembelajaran problem solving tentunya terdapat kelebihan dan kelemahan dalam melaksanakan pembelajaran. Kelebihan metode pembelajaran problem solving yakni siswa mampu mancari pemecahan masalah yang dihadapi atau disajikan guru dengan merefleksikan dengan lingkungan masyarakat, mendidik siswa berpikir secara kritis dalam menganalisa masalah, dan mendidik siswa untuk berani mengemukakan pendapat dan bertanya sehingga memunculkan rasa percaya diri pada siswa. Sedangkan kelemahan dari metode pembelajaran problem solving adalah pembelajaran cukup memerlukan waktu, siswa pasif kurang memiliki keberanian dalam mengungkapkan ide dan pemikirannya, dan terdapat beberapa siswa yang mendominasi pembelajaran.

\section{Strategi Pembelajaran Problem Solving}

Menurut Gerlach dan Ely strategi pembelajaran dikatakan berkaitan dengan cara penyampaian materi dalam lingkungan pembelajaran yang meliputi sifat, ruang lingkup dan urutan peristiwa yang memberikan pengalaman-pengalaman pendidikan (Depdiknas, 2003: 11). Strategi pembelajaran tersusun memungkinkan pembelajaran untuk mencapai tujuan-tujuan belajar. Strategi pembelajaran diartikan sebagai pola umum pembelajaran siswa, dimana pembelajaran tersusun 
secara sistematis berdasarkan prinsip-prinsip pendidikan, didaktik dan komunikasi dengan mengintegrasikan struktur (urutan/langkah kegiatan) pembelajaran, metode pembelajaran, media pembelajaran/alat peraga, pengelolaan kelas, evaluasi dan waktu yang diperlukan agar siswa dapat mencapai tujuan-tujuan pembelajaran secara efektif dan efisien.

Strategi pembelajaran penyelesaian masalah merupakan bagian dari strategi belajar inkuiri. Menurut Dewey penyelesaian masalah ada enam tahap (Hudojo, 2003: 163), yakni: (1) merumuskan masalah: mengetahui dan menemukan amsalah secara jelas; (2) menelaah masalah: menggunakan pengetahuan untuk memperinci, menganalisis masalah dari berbagai sudut; (3) merumuskan hipotesis: berimajinasi dan menghayati ruang lingkup, sebab akibat dan alternatif penyelesaian; (4) mengumpulkan dan mengelompokkan data sebagai bahan pembuktian hipotesis: kecakapan mencari dan menyusun data, menyajikan data dalam bentuk diagram dan gambar; (5) pembuktian hipotesis: cakap menelaah dan membahas data, menghitung dan menghubungkan, ketrampilan mengambil keputusan dan kesimpulan; dan (6) menentukan pilihan penyelesaian: kecakapan membuat alternatif kecakapan menilai pilihan dengan memperhitungkan akibat yang akan terjadi pada setiap langkah.

Strategi pembelajaran penyelesaian masalah/problem solving juga dipengaruhi oleh kemampuan guru dalam memotivasi dan merangsang siswa dalam menyelesaikan masalah yang dihadapi dengan menggunakan media/alat peraga serta kondisi lingkungan pembelajaran yang diciptakan lebih kondusif, sehingga siswa mampu berkomunikasi, berani mengungkapkan pendapat, percaya diri dalam bertanya dan menjawab, serta meningkatkan kemampuan siswa dalam berpikir kritis terhadap masalah-masalah sosial di masyarakat.

\section{METODE PENELITIAN}

\section{Setting Penelitian}

Penelitian dilakukan di SD Negeri Kasepuhan Sewon Bantul, dengan subjek penelitian siswa kelas V dengan jumlah siswa 32 siswa. Alasan pemilihan subjek tersebut dikarenakan pembelajaran IPS di SD tersebut kurang maksimal dan kurang memuaskan, hal ini disebabkan karena guru hanya menggunakan metode ceramah yang monoton sehingga pembelajaran IPS menjadi kurang menarik, guru tidak menggunakan media/alat peraga yang tepat sehingga siswa mengalami kesulitan dalam memahami teori yang disampaikan guru, siswa tidak dilibatkan dalam pembelajaran yang sedang berlangsung, dan siswa hanya menghafal konsep dan teori tidak mengalami pembelajaran secara langsung sehingga siswa kurang termotivasi untuk berpikir kritis dan kurang terampil serta kesulitan dakam menghadapi masalah dikehidupan sehari-hari.

\section{Prosedur Penelitan}

a. Rancangan Penelitian

Penelitian ini menggunakan desain penelitian tindakan kelas (classroom action research) yang berusaha mengkaji dan merefleksi secara mendalam beberapa aspek dalam kegiatan belajar mengajar yaitu keaktifan siswa dalam pembelajaran, kemampuan siswa dalam mengungkapkan pendapat dan bertanya, serta kemampuan siswa berpikir kritis dalam memecahkan masalah. Desain penelitian penelitian tindakan kelas Model Lewin diilustrasikan pada Gambar 1. 


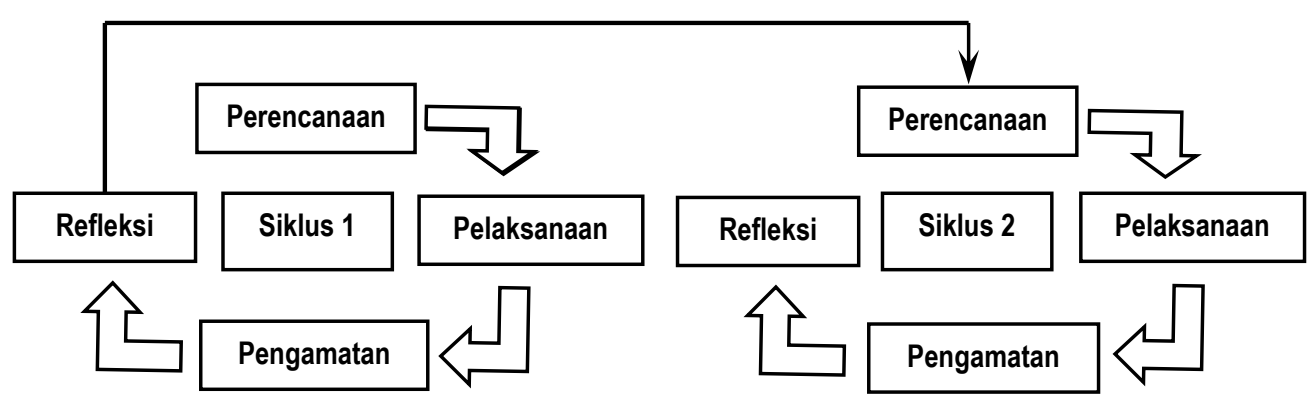

\section{Gambar 1 Desain Penelitian Tindakan Kelas}

b. Pelaksanaan Penelitian

Penelitian ini menggunakan penelitian tindakan kelas yang terdiri dari dua siklus, Tiap siklus terdiri dari empat tahap yakni perencanaan, tindakan, pengamatan dan refleksi. Dari tiap siklus diamati kualitas pembelajaran dengan menggunakan metode pembelajaran problem solving yang terdiri dari keaktifan siswa dalam pembelajaran, dan kemampuan guru dalam memotivasi siswa dalam berpikir kritis dan menganalisa masalah yang disajikan guru.

1) Siklus 1

a) Tahap Perencanaan Tindakan

Pada tahap perencanaan ini, peneliti berkolaborasi dengan guru melakukan pra penelitian dengan mengamati terlebih dahulu permasalahan yang muncul dalam pembelajaran IPS, melihat keefektivan penggunaan metode dan media yang digunakan guru dalam proses pembelajaran, dan partisipasi siswa dalam pembelaajran. Setelah mengamati permasalahan yang muncul di lapangan, peneliti bekerjasama dengan guru merancang tindakan yang sebaiknya dilakukan agar pembelajaran pada materi kegiatan ekonomi di Indonesia menjadi lebih interaktif dan menarik.

Sehingga dirancanglah langkah-langkah perencanaan, yaitu: (1) menyusun rencana perbaikan pembelajaran mata pelajaran IPS melalui pembelajaran problem solving; (2) merencanakan langkah-angkah kegiatan pembelajaran IPS melalui pembelajaran problem solving; (3) meyusun pedoman pengamatan dan pedoman wawancara dalam pelaksanaan pembelajaran IPS melalui pembelajaran problem solving; dan (4) merencanakan media/alat peraga yang akan digunakan beserta pertanyaan berupa masalah yang akan disajikan dalam pembelajaran.

b) Tahap Pelaksanaan Tindakan

Tahap ini merupakan pelaksanaan dari rancangan yang telah disusun sebelumnya. Pelaksanaan tindakan berupa pelaksanaan pembelajaran IPS melalui pembelajaran problem solving secara riil di kelas V SD Negeri Kasepuhan Sewon Bantul. Pelaksanaan penelitian peneliti berkolaboasi dengan guru dan teman sejawat dalam rangka pengumpulan data penelitian. Pelaksanaan tindakan dilakukan dengan rangkaian siklus-siklus secara berulang. Siklus I dilakukan $2 \mathrm{x}$ jam pelajaran selama 60 menit, dan siklus II dilakukan $2 \times$ jam pelajaran selama 60 menit, jika semua indikator tercapai maka siklus akan diakhiri.

c) Tahap Pengamatan

Pada tahap pengamatan, peneliti berkolaborasi dengan guru mengamati secara intensif pelaksanaan pembelajran IPS melalui pembelajaran problem solving di kelas V SD Negeri Kasepuhan Sewon Bantul. Hal-hal yang dilakukan oleh 
peneliti yakni mengamati dan mencatat semua gejaa yang muncul baik yang mendukung maupun yang menghambat dalam pembelajaran IPS, mencatat atau merekam gejala yang muncul dalam pembelajaran pada lembar observasi berupa catatan check list, kemudian data diseleksi dan dianalisis menggunakan cara deskriptif kualitatif.

d) Tahap Refleksi

Pada tahap refleksi, peneliti dan guru mengulas kembali pelaksanaan tindakan ada siklus I, apabila target yang telah ditetapkan belum tercapai dan pembelajaran dianggap kurang atau perlu adanya perbaikan, maka perlu adanya siklus II untuk memperbaiki pembelajaran pada siklus I. Harapannya pada siklus II pembelajaran menjadi lebih maksimal.

\section{2) Siklus 2}

Pada siklus II pembelajaran IPS dengan menggnakan problem solving dilakukan sama tahapannya, yakni dari perencanaan, pelaksanaan tindakan, pengamatan dan refleksi. Pada siklus II gaya mengajar yang dilakukan guru dan peneliti pada siklus I diperbaiki agar pembelajaran menjadi lebih berkualitas. Selain itu guru dan peneliti perlu memperbaiki media/alat peraga dan pengendalian suasana kelas agar lebih kondusif, guru perlu memotivasi siswa agar lebih memiliki keberanian dalam mengeluarkan pendapat dan meningkatkan rasa percaya diri siswa untuk berinteraksi dengan baik. Harapannya pada siklus II target yang diharapkan tercapai.

\section{Data dan Cara Pengumpulan Data}

a. Sumber dan Jenis Data

Sumber data penelitian berasal dari seluruh anggota tim penelitian dan siswa kelas V sebagai objek dari penelitian sebanyak 32 siswa. Jenis data pada penelitian ini adalah data kualitatif yakni berupa pengukuran kemampuan siswa dalam memecahkan masalah dengan tolak ukur keaktifan siswa, keberanian siswa dalam bertanya, kemampuan siswa dalam mengemukakan pendapat secara kritis, kemampuan siswa dalam menganalisa masalah, kemampuan siswa dalam merespon balik permasalahan, serta kemmapuan siswa dalam memecahkan masalah secara mendalam. Sedangkan untuk standar angka pengukuran hasil dari data kualitatif menggunakan data deskripsi kuantitatif.

b. Teknik Pengambilan Data

Teknik pengambilan data dalam penelitian ini mengunakan lembar observasi (untuk mengetahui aktivitas pembelajaran IPS dengan menggunakan pembelajaran problem solving), Catatan lapangan pada saat pembelajaran berlangsung, Wawancara yang dilakukan terhadap siswa dan guru, Dokumentasi berupa hasil belajar problem solving juga dokumentasi beruba gambar/foto/video aktivitas pembelajaran.

\section{c. Teknik Analisa Data}

Teknik analisa data yang digunakana adalah teknik deskriptif analitik yakni data kuantitatif menggunakan persentase, sedangkan data kualitatif untuk memperjelas data kuantitatif. 


\section{d. Indikator Kinerja}

Keberhasilan dalam penelitian ini diukur dengan adanya penigkatan kemampuan siswa dalam mengatasi masalah dengan target jumlah siswa yang mengalami peningkatan 22 siswa dari jumlah siswa 32 siswa.

\section{HASIL PENELITIAN DAN PEMBAHASAN}

Penelitian ini bertujuan untuk melihat keaktifan siswa dalam pembelajaran, kemampuan siswa dalam bertanya, kemampuan siswa dalam mengeluarkan pendapat, kemampuan siswa dalam berpikir kritis dan menganalisa masalah yang disajikan guru. Penelitian ini dilakukan dalam 2 siklus. Sebelum melakukan tindakan, peneliti berkolaborasi dengan guru melakukan prapenelitian. Hasil prapenelitian disajikan pada Tabel 1.

\section{Tabel 1 Hasil Prapenelitian}

\begin{tabular}{clcc}
\hline No & \multicolumn{1}{c}{ Aktivitas } & Jumlah Siswa & Persentase \\
\hline 1 & Keaktifan siswa dalam pembelajaran & 5 & $16 \%$ \\
2 & Kemampuan bertanya & 4 & $13 \%$ \\
3 & Kemampuan mengeluarkan pendapat & 7 & $22 \%$ \\
4 & Kritis dalam menganalisa masalah & 2 & $6 \%$ \\
\hline
\end{tabular}

Berdasarkan prapengamatan tersebut terlihat bahwa pembelajaran pada pelajaran IPS kurang efektif, terlihat keaktifan dalam pembelajaran hanya 5 siswa sebanyak $16 \%$, siswa yang bertanya hanya 4 siswa (13\%), kemampuan siswa dalam mengeluarkan pendapat sebanyak 7 siswa (22\%), dan siswa kritis dalam menganalisa masalah sebanyak 2 siswa (6\%). Hal ini membukutikan bahwa masih banyak siswa yang pasif dalam pembelajaran. Setelah mengetahui hasil pra penelitian tersebut, peneliti berkolaborasi dengan guru melakukan pembelajaran problem solving pada siklus I. Hasil penelitian dan pembahasan dari siklus 1 adalah sebagai berikut:

Tabel 2 Hasil Penelitian Siklus 1

\begin{tabular}{clcc}
\hline No & \multicolumn{1}{c}{ Aktivitas } & Jumlah Siswa & Persentase \\
\hline 1 & Keaktifan siswa dalam pembelajaran & 10 & $31 \%$ \\
2 & Kemampuan bertanya & 15 & $47 \%$ \\
3 & Kemampuan mengeluarkan pendapat & 12 & $38 \%$ \\
4 & Kritis dalam menganalisa masalah & 17 & $53 \%$ \\
\hline
\end{tabular}

Berdasarkan hasil penelitian pembelajaran pada pelajaran IPS di siklus 1 diketahui bahwa keaktifan siswa mulai meningkat sebanyak 10 siswa (31\%), siswa sudah termotivasi untuk bertanya bagaimana memecahkan permasalahan yang diajukan sebanyak 15 siswa (47\%), siswa sudah berani berpendapat dalam pembelajaran problem solving sebanyak 12 siswa (38\%), dan siswa sudah mampu berpikir kritis terhadap masalah yang disajikan untuk dipecahkan sebanyak 17 siswa (53\%). Hal ini menunjukkan bahwa siswa menjadi lebih termotivasi belajar dengan menggunakan metode problem solving. Namun setelah dilakukan refleksi, ternyata pencapaian hasil belum mencapai indikator keberhasilan sehingga dilakukan kembali tahapan tindakan di siklus 2, harapannya di siklus 2 terdapat perbaikan pembelajaran. Pembelajaran pada pelajaran IPS di siklus 2 dengan 
metode yang sama yakni metode pembelajaran problem solving namun gaya mengajar lebih interaktif, diketahui hasil penelitian pada Tabel 3.

Tabel 3 Hasil Penelitian Siklus 2

\begin{tabular}{clcc}
\hline No & \multicolumn{1}{c}{ Aktivitas } & Jumlah siswa & Persentase \\
\hline 1 & Keaktifan siswa dalam pembelajaran & 28 & $88 \%$ \\
2 & Kemampuan bertanya & 25 & $78 \%$ \\
3 & Kemampuan mengeluarkan pendapat & 26 & $81 \%$ \\
4 & Kritis dalam menganalisa masalah & 24 & $75 \%$ \\
\hline
\end{tabular}

Berdasarkan data di atas terlihat bahwa terdapat peningkatan pembelajaran siswa pada pelajaran IPS dengan menggunakan metode problem solving. Hal ini dibuktikan dengan adanya peningkatan keaktifan siswa dalam pembelajaran sebanyak 28 siswa (88\%), Kemampuan siswa dalam bertanya sebanyak 25 siswa (78\%), Kemampuan siswa dalam mengeluarkan pendapat dalam pembelajaran problem solving sebanyak 26 siswa (81\%) dan siswa telah mampu berpikir kritis terhadap masalah yang disajikan untuk dipecahkan sebanyak 24 siswa (75\%). Pada siklus 2 telah mencapai target atau indikator keberhasilan kinerja, sehingga penelitian ini berakhir di siklus 2. Untuk memperjelas peningkatan pembelajarn IPS dengan menggunakan metode problem solving terlihat pada Grafik 1.

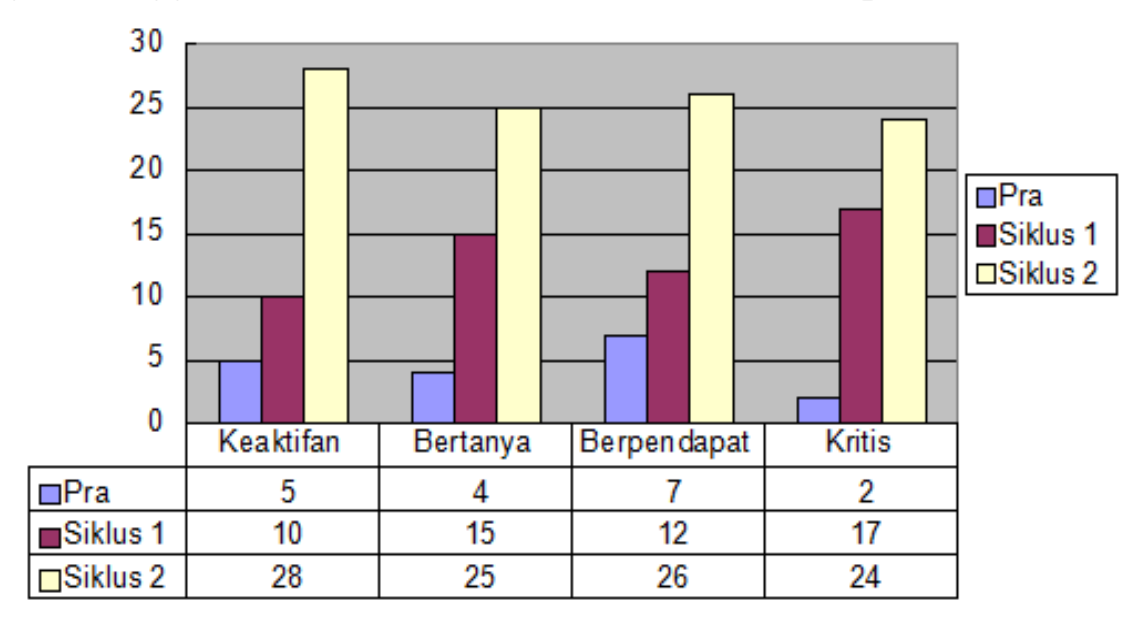

\section{Grafik 1 Hasil Penelitian}

Pembelajaran pada pelajaran IPS yang dilakukan guru dengan berceramah pada tahap prapenelitian terlihat bahwa keaktifan siswa dalam pembelajaran hanya 5 siswa (16\%), sedangkan pada siklus 1 yang telah diterapkan pembelajaran dengan menggunakan metode problem solving yakni 10 siswa $(31 \%)$, dan terjadi peningkatan yang signifikan di siklus 2 yakni 28 siswa (88\%). Hal ini membuktikan bahwa pembelajaran menggunakan metode problem solving mampu meningkatkan keaktifan dan partisipasi siswa dalam pembejaran. Pada kemampuan bertanya pada saat pra penelitian hanya 4 siswa $(13 \%)$ yang berani bertanya pada guru, sedangkan pada siklus 1 dan siklus 2 mengalami peningkatan yakni sebanyak 15 siswa (47\%) dan 25 siswa (78\%). Hal ini membuktikan bahwa siswa telah berani dan percaya diri untuk bertanya mengenai masalah yang diajukan guru dan berkomunikasi dalam pembelajaran. 
Kemampuan siswa dalam mengeluarkan pendapat juga mengalami peningkatan, yakni pada saat pra penelitian hanya 7 siswa $(22 \%)$, sedangkan pada saat diterapkan metode problem solving terdapat 12 siswa (38\%) pada siklus 1 dan 26 siswa (81\%) pada siklus 2 yang mampu mengeluarkan pendapat dalam rangka memecahkan masalah yang disajikan guru. Hal ini membuktikan bahwa terdapat komunikasi positif dalam pembelajaran sehingga siswa menjadi nyaman untuk berinteraksi dan mengeluarkan pendapatnya dalam pembelajaran. Sedangkan kemampuan siswa dalam berpikir kritis dalam menganalisa masalah juga mengalami peningkatan dari sebelumnya hanya 2 siswa $(6 \%)$ pada pra penelitian menjadi meningkat setelah dilakukan pembelajaran problem solving yakni sebanyak 17 siswa (53\%) pada siklus 1 dan 24 siswa (75\%) pada siklus 2 . Hal ini menunjukkan bahwa metode problem solving mampu meningkatkan kemampuan siswa dalam berpikir kritis dalam memecahkan masalah yang disajikan guru dalam pembelajaran.

\section{E. KESIMPULAN DAN SARAN}

Hasil penelitian menunjukkan terdapat peningkatan pembelajaran dengan menggunakan metode problem solving, yakni: (1) keaktifan siswa dalam pembelajaran dari prapenelitian ada 5 siswa yang aktif, setelah diterapkan metode pembelajran problem solving terjadi peningkatan yakni pada siklus 1 terdapat 10 siswa yang aktif dan siklus 2 terdapat 28 siswa; (2) kemampuan siswa dalam mengajukan pertanyaan ketika pembelajaran berlangsung mengalami peningkatan, dari prapenelitian hanya sebanyak 4 siswa, pada saat penerapan pembelajaran problem solving pada siklus 1 sebanyak 15 siswa dan siklus 2 terdapat 25 siswa; (3) kemampuan siswa dalam mengeluarkan pendapat mengalami penngkatan, sebelumnya pada prapenelitian sebanyak 7 siswa, pada saat penerapan metode problem solving mengalami peningkatan sebanyak 12 siswa pada siklus 1 dan siklus 2 sebanyak 26 siswa; dan (4) kemampuan siswa dalam berpikir kritis dalam menganalisa masalah yang disajikan mengalami peningkatan sebelumnya hanya 2 siswa (pada prapenelitian), pada saat pembelajaran problem solving mengalami peningkatan sebanyak 17 siswa pada siklus 1 dan 24 siswa pada siklus 2 .

Hal ini menunjukkan pembelajaran menggunakan problem solving dapat meningkatkan kemampuan siswa dalam pembelajaran IPS. Berdasarkan kesimpulan penelitian tersebut, saran yang disampaikan yakni: (1) guru hendaknya menggunakan metode pembelajaran yang mampu mengaktifkan pembelajaran IPS salah satunya metode problem solving; (2) guru sebaiknya menggunakan media pembelajaran yang mendukung pembelajaran; dan (3) guru hendaknya meningkatkan komunikasi, partisipasi, dan interaksi pembelajaran terutama menggunakan pembelajaran problem solving. 


\section{DAFTAR RUJUKAN}

Hudojo. 2003. Media dalam Pembelajaran. Jakarta: Pusat Sumber Belajar.

Hamalik, O. 1994. Media Pendidikan. Bandung: Citra Aditya Bakti.

Nawawi, H. 1993. Metode Penelitian Bidang Sosial. Yogyakarta: Universitas Gajahmada Yogyakarta.

Saidiharjo. 2002. Pengembangan Materi IPS Terpadu. Yogyakarta: Program Pascasarjana Universitas Negeri Yogyakarta.

Sardiman. 1992. Interaksi dan Motivasi Belajar Mengajar. Bandung: Rajawali Press.

Subyantoro. 2009. Penelitian Tindakan Kelas. Semarang: Universitas Diponegoro Semarang.

Tim PPPG IPS. 2005. Materi Pembelajaran IPS untuk SMP. Surabaya: Tim PPPG IPS. 